\title{
Review Article \\ Hydrogen Peroxide and Sodium Transport in the Lung and Kidney
}

\author{
V. Shlyonsky, ${ }^{1}$ A. Boom, ${ }^{2}$ and F. Mies ${ }^{1}$ \\ ${ }^{1}$ Laboratoire de Physiologie et Pharmacologie, Université Libre de Bruxelles, 1070 Bruxelles, Belgium \\ ${ }^{2}$ Laboratoire d'Histologie, Histopathologie et Neuroanatomie, Université Libre de Bruxelles, 1070 Bruxelles, Belgium \\ Correspondence should be addressed to V. Shlyonsky; vshlyons@ulb.ac.be
}

Received 15 January 2016; Revised 4 March 2016; Accepted 8 March 2016

Academic Editor: Hartmut Jaeschke

Copyright (c) 2016 V. Shlyonsky et al. This is an open access article distributed under the Creative Commons Attribution License, which permits unrestricted use, distribution, and reproduction in any medium, provided the original work is properly cited.

Renal and lung epithelial cells are exposed to some significant concentrations of $\mathrm{H}_{2} \mathrm{O}_{2}$. In urine it may reach $100 \mu \mathrm{M}$, while in the epithelial lining fluid in the lung it is estimated to be in micromolar to tens-micromolar range. Hydrogen peroxide has a stimulatory action on the epithelial sodium channel $(\mathrm{ENaC})$ single-channel activity. It also increases stability of the channel at the membrane and slows down the transcription of the $\mathrm{ENaC}$ subunits. The expression and the activity of the channel may be inhibited in some other, likely higher, oxidative states of the cell. This review discusses the role and the origin of $\mathrm{H}_{2} \mathrm{O}_{2}$ in the lung and kidney. Concentration-dependent effects of hydrogen peroxide on $\mathrm{ENaC}$ and the mechanisms of its action have been summarized. This review also describes outlooks for future investigations linking oxidative stress, epithelial sodium transport, and lung and kidney function.

\section{Introduction}

It is generally accepted that cells in most tissues are exposed to some level of $\mathrm{H}_{2} \mathrm{O}_{2}$ and locally this level may reach significantly high concentrations. Multiple studies have reported that high levels of $\mathrm{H}_{2} \mathrm{O}_{2}$ (usually $>100 \mu \mathrm{M}$ ) are cytotoxic to a wide range of animal, plant, and bacterial cells in culture, although $\mathrm{LD}_{50}$ values depend on the cell type, length of exposure, and the cell culture conditions [1-5]. It is therefore widely thought that $\mathrm{H}_{2} \mathrm{O}_{2}$ is very toxic in vivo and must be rapidly eliminated. It is, however, paradoxical that patients with acatalasemia (autosomal recessive peroxisomal disorder caused by a complete lack of catalase that neutralizes $\mathrm{H}_{2} \mathrm{O}_{2}$ ) rarely have health problems [1]. Knockout of glutathione peroxidase, enzyme that also reduces free hydrogen peroxide to water, does not induce any particular phenotype $[6,7]$. This suggests that hydrogen peroxide besides participation in innate immunity may have also important signaling and/or regulatory role in living organisms [8].

Ion transport by the lung epithelial cells is the major mechanism that maintains optimal level of lining airway and alveolar liquid. This in turn determines efficient aeration of the lung and facilitates diffusion of gases across the alveolarcapillary walls. In the kidney, sodium reabsorption in different parts of nephron regulates fluid balance and thus blood pressure. Therefore, intracellular signaling cascades that regulate ion transport mediated by ion channels are of particular interest for any fundamental and clinical investigation of the lung and kidney function. The role of reactive oxygen species [ROS] in modulation of ion channels activity has been recently recognized. Ion channels regulation by these reactive species may occur in several different ways [9]. First way is through direct oxidation of key amino acid residues of channel proteins. Second, reactive species may alter the activity of other signaling mechanisms that secondarily lead to changes in channel activity or channel gene expression. At last, there are more complex mechanisms mediated through alterations in trafficking or turnover of channel proteins through changes in proteasomal degradation of channels (rew in [9]).

The purpose of this review is to explain the role and the origin of $\mathrm{H}_{2} \mathrm{O}_{2}$ in lung and kidney and its concentrationdependent effects on sodium transport, particularly on epithelial sodium channel $(\mathrm{ENaC})$. This review also 
describes outlooks for future investigations linking oxidative stress, epithelial sodium transport, and lung and kidney function.

\section{Sources of $\mathrm{H}_{2} \mathrm{O}_{2}$ and Estimation of In Situ Concentration}

2.1. Lung. Reactive oxygen species (ROS) in the lung may have exogenous and endogenous origin. First, ROS may be present in inhaled air that contains cigarette smoke, environmental pollutants, and oxidant gases. Alternatively, hydroperoxides [e.g., $\mathrm{H}_{2} \mathrm{O}_{2}$ ], superoxide anions, and hydroxyl free radicals can be generated by activated inflammatory cells [such as neutrophils, eosinophils, and alveolar macrophages] and by epithelial and endothelial cells themselves [10]. These cellular ROS are formed as intermediates of the incomplete reduction of oxygen in mitochondrial electron-transport systems, by microsomal metabolism of endogenous compounds and xenobiotics, or by various enzymatic generators, such as xanthine oxidase. Endothelial, inflammatory cells and pneumocytes generate and release ROS via an NADPH oxidasedependent mechanism, which is mediated by membrane receptor activation of phospholipase $\mathrm{C}$ leading to elevation of intracellular calcium level [11]. Finally, there is convincing data suggesting that hydrogen peroxide, produced in small intestine, enters mesenteric lymph and finds its way to the lung [12].

Production of $\mathrm{H}_{2} \mathrm{O}_{2}$ has been detected both in alveolar cell cultures in vitro [13-16] and in the exhaled breath of humans $[17,18]$. ROS in exhaled breath condensate (EBC) have been measured in different inflammatory lung diseases (asthma, chronic obstructive pulmonary disease, cystic fibrosis, etc.) with majority of the clinical reports showing increased ROS concentration in patients compared with normal subjects $[17,18]$. Lack of or very weak correlation of ROS levels in EBC with other biological fluids such as bronchoalveolar lavage liquid and sputum have been also reported [19]. High variability of the measurements for the same subjects was also observed and levels of $\mathrm{H}_{2} \mathrm{O}_{2}$ showed correlation with circadian rhythms and the diet. Maximal concentration of hydrogen peroxide, the most abundant ROS species in the lung, does not exceed $0.9 \mu$ moles per liter of EBC obtained from normal subjects [17-19]. The major difficulty consists in translation of this value into the concentration of $\mathrm{H}_{2} \mathrm{O}_{2}$ in alveolar lining fluid, that is, in situ concentration. Hydrogen peroxide has much lower volatility as compared to water and there exists exponential relationship between the molar $\mathrm{H}_{2} \mathrm{O}_{2} / \mathrm{H}_{2} \mathrm{O}$ fraction in the solution and in the vapor phase [20]. However, since micromolar concentration of $\mathrm{H}_{2} \mathrm{O}_{2}$ in $\mathrm{EBC}$ gives molar ratio in vapor phase of $1.8 * 10^{-8}$, it is impossible to extrapolate the existing data on molar fractions in liquid phase to such a low value.

Alternative way to estimate absolute $\mathrm{H}_{2} \mathrm{O}_{2}$ concentration in situ is to measure peroxide concentration in bronchoalveolar lavage fluid (BALF) and correct the value by a factor obtained by urea dilution technique [21]; however, no research groups have done it so far. Nevertheless, there are published reports with separate data on hydrogen peroxide concentration in BALF and on alveolar lining fluid volume. In normal human lungs, alveolar lining fluid volume fluctuates within the range of $0.2-2.0 \mathrm{~mL}$ [22-26], while in rats this volume has been found to be within the range of $0.03-0.26 \mathrm{~mL}$ [27-29]. Since commonly used volume of liquid for bronchoalveolar lavage in humans is $100 \mathrm{~mL}$ and $5 \mathrm{~mL}$ in rats, the expected dilution factor is likely to be $\sim 100$ in normal lungs [30]. Knowing that the concentration of $\mathrm{H}_{2} \mathrm{O}_{2}$ in BALF is $0.14-0.70 \mu \mathrm{M}$ in rats [31, 32] and $0.08 \mu \mathrm{M}$ in humans [33], actual hydrogen peroxide concentrations in the lungs in situ may be well expected in micromolar to tens-micromolar range. However, these are just approximations and they warrant further studies.

2.2. Kidney, Urinary Tract, and Bladder. Freshly voided human urine may contain substantial quantities of $\mathrm{H}_{2} \mathrm{O}_{2}$, at concentrations sometimes exceeding $100 \mu \mathrm{M}$ [34-36]. The $\mathrm{H}_{2} \mathrm{O}_{2}$ detected in human urine appears to arise, at least in part, by $\mathrm{O}_{2}{ }^{--}$-dependent autoxidation of urinary molecules $[36,37] . \mathrm{H}_{2} \mathrm{O}_{2}$ can be generated by activated phagocytes in urine and can be generated in the kidney by NADPH oxidases. Indeed, reactive oxygen species are produced by fibroblasts, endothelial cells, vascular smooth muscle cells, mesangial cells, tubular cells, and podocytes cells [38]. NOX1 and NOX-4 are expressed in the kidney, with a prominent expression in renal vessels, glomeruli, and podocytes, and cells of the thick ascending limb of the loop of Henle, macula densa, distal tubules, collecting ducts, and cortical interstitial fibroblasts [38]. NADPH oxidase activity is upregulated by prolonged infusion of angiotensin II or by a high salt diet [38]. The high levels of $\mathrm{H}_{2} \mathrm{O}_{2}$ that can be detected in some urine samples strongly suggest that at least some $\mathrm{H}_{2} \mathrm{O}_{2}$ generation occurs within the bladder. Urinary levels of $\mathrm{H}_{2} \mathrm{O}_{2}$ can also be increased by diet supplement (e.g., coffee drinking), by enzymatic reaction directly in urine, and by general oxidative stress. This suggests possibility that excretion of $\mathrm{H}_{2} \mathrm{O}_{2}$ represents a metabolic mechanism for controlling its levels in the human body. Accordingly, a measurement of urinary $\mathrm{H}_{2} \mathrm{O}_{2}$ levels represents a valuable tool for assessment of oxidative stress, since $\mathrm{H}_{2} \mathrm{O}_{2}$ can be quantified very fast and with high precision.

2.3. Blood. Hydrogen peroxide observed in the lung and the kidney might finally find its way from the blood. Some studies have claimed substantial levels of $\mathrm{H}_{2} \mathrm{O}_{2}$ (up to $\sim 35 \mu \mathrm{M}$ ) in human blood plasma [39-41]. However, these studies have been performed under assay conditions in which removal of $\mathrm{H}_{2} \mathrm{O}_{2}$ was prevented. This implies that human plasma may continuously generate $\mathrm{H}_{2} \mathrm{O}_{2}$. One enzyme involved in this process, at least under pathological conditions, appears to be xanthine oxidase [42]. In the plasma, $\mathrm{H}_{2} \mathrm{O}_{2}$ can react with heme proteins, ascorbate, and protein- $\mathrm{SH}$ groups and it is degraded by the traces of catalase present, and thus, under conditions of keeping normal antioxidant mechanisms, levels of $\mathrm{H}_{2} \mathrm{O}_{2}$ are reported to be very low, close to zero [43]. 


\section{Regulation of Sodium Channels by Hydrogen Peroxide}

Recent studies suggest that the expression and the activity of $\mathrm{ENaC}$ may be regulated by the oxidative state of the cell. Direct application of $100 \mu \mathrm{M} \mathrm{H}_{2} \mathrm{O}_{2}$ to $\mathrm{A} 6$ distal nephron cells upregulates $\mathrm{ENaC}$ open probability and equivalent transepithelial sodium open-circuit current [44-47]. Furthermore, pharmacological inhibition of NADPH oxidase NOX-4 by fulvene-5 in A6 cells downregulates ENaC activity [47]. Thus, this suggests that tonical production of $\mathrm{H}_{2} \mathrm{O}_{2}$ by NOX-4 supports single-channel activity of ENaC. Similar stimulatory effect of exogenous $\mathrm{H}_{2} \mathrm{O}_{2}$ at $250 \mu \mathrm{M}$ has been obtained by Downs and colleagues in lung epithelial cells [48]. They have shown that single-channel activity of both highly selective and nonselective ENaCs is upregulated in type 2 pneumocytes [48]. In our experiments on formation of epithelial domes on nonporous support, which is reflective of $\mathrm{ENaC}$ activity [49], catalase and superoxide scavenger TEMPO inhibited up to $80 \%$ of dexamethasone-induced dome formation in $\mathrm{H} 441$ lung epithelial cells and submillimolar concentrations of $\mathrm{H}_{2} \mathrm{O}_{2}$ could alone transiently stimulate this dome formation [our unpublished data].

Another reactive oxygen species, superoxide anions $\mathrm{O}_{2}{ }^{--}$ produced by NOX-2, has been shown to positively regulate ENaC activity in alveolar cells [50]. Superoxide anion may have also indirect stimulatory action on $\mathrm{ENaC}$ single-channel activity by neutralizing $\mathrm{NO}$ that decreases ENaC activity [51]. In addition, agents that increase local superoxide concentration (mixture of hypoxanthine compounds and xanthine oxidase) stimulate single-channel activity of $\mathrm{ENaC}$ in $\mathrm{A} 6$ epithelial cells [52].

At the level of protein expression, exogenous hydrogen peroxide has been shown to inactivate ubiquitination of lung $\alpha$-ENaC, thus increasing its surface expression [48]. But at the level of gene expression, contrasting effects of $\mathrm{H}_{2} \mathrm{O}_{2}$ on $\alpha$-, $\beta$-, and $\gamma$-ENaC have been reported $[48,53$, 54]. While low doses below $0.25 \mathrm{mM}$ have no significant effect on transcription [48], near millimolar concentrations of $\mathrm{H}_{2} \mathrm{O}_{2}$ suppress $\alpha$-ENaC transcription $[53,54]$. In type II pneumocytes, cyclic AMP and activation of glucocorticoid receptors stimulate the expression and activity of ENaCs as well as the expression of $\mathrm{H}_{2} \mathrm{O}_{2}$ producing NADPH oxidase DUOX1 $[15,55]$, which leaves the possibility for a speculation that long-term activation of single-channel activity of $\mathrm{ENaC}$ by cAMP and dexamethasone might be in part related to $\mathrm{H}_{2} \mathrm{O}_{2}$ production by DUOX1.

Molecular mechanisms of $\mathrm{ENaC}$ activity stimulation by $\mathrm{H}_{2} \mathrm{O}_{2}$ seem to involve activation of PI3-kinases that produce anionic phospholipids phosphatidylinositol-4,5bisphosphate, PIP2, and phosphatidylinositol-3,4,5-trisphosphate, PIP3 [44-46]. In addition to activation of PI3 kinase, increase in PIP3 in A6 cells in the presence of $\mathrm{H}_{2} \mathrm{O}_{2}$ may be explained at least in part by inactivation of PTEN that negatively regulates intracellular levels of PIP3 [56, 57]. PIP2 and PIP3 in turn bind to $\mathrm{ENaC}$ or participate in other signaling cascades and by doing so modulate cellular sodium transport (rew in [58]). In this regard it has been shown that epidermal growth factor (EGF), insulin, insulin growth factor-1 (IGF-1), and prorenin have a common stimulatory effect on $\mathrm{ENaC}$ in renal cells that is mediated by ROS production and hydrogen peroxide in particular $[59,60]$. In lung epithelial cells, hydrogen peroxide produced by DUOX1 extracellularly may reenter the cell, where it activates PI3kinase, which in turn stimulates $\mathrm{ENaC}$ activity. Catalase action suggests that hydrogen peroxide has no feedback effect on DUOX1 gene expression, while there is possibility that it may negatively regulate $\mathrm{ENaC}$ transcription [42, our unpublished observations]. Taken together, stimulation of ion transport activity of $\mathrm{ENaC}$ and its stabilization at the cell surface by decreasing ubiquitination by $\mathrm{H}_{2} \mathrm{O}_{2}$ might be balanced at least in the lung by negative feedback of hydrogen peroxide on the $\mathrm{ENaC}$ transcription.

The above stimulatory action of hydrogen peroxide on $\mathrm{ENaCs}$ contrasts the reports obtained in studies with severe oxidant stress on lung epithelial cells, in which downregulation of sodium transport has been reported. In lung epithelial cell monolayer studies, severe oxidative stress induced by millimolar concentrations of $\mathrm{H}_{2} \mathrm{O}_{2}$ alters epithelial ion transport mechanisms by decreasing short-circuit current $\left(I_{\mathrm{sc}}\right)$ and monolayer resistance $(R)$, while being more effective from the basolateral (serosal) side [61]. In this study, the effective concentration of apical $\mathrm{H}_{2} \mathrm{O}_{2}$ at which $I_{\text {sc }}$ was decreased by $50 \%$ was absolutely nonphysiological and equal to $4 \mathrm{mM}$ [61]. It has been also reported that exogenous hydrogen peroxide in excess of $200 \mu \mathrm{M}$ interferes with glucocorticoid-induced transcription of $\alpha$-ENaC subunit in A549, H441, and Calu-3 lung epithelial cells $[53,54]$.

Another way to create a condition of severe oxidative stress consists in application of significant concentration of glutathione disulfide (GSSG). Zhang and colleagues have reported nanomolar concentrations of GSSG in one milliliter of medium obtained after lysis of $2 * 10^{5}$ HL60 cells [62]. For a cell of $10 \mu \mathrm{m}$ in diameter having cellular volume of approximately $0.5 \mathrm{pL}$, this corresponds to a $10^{4}$ dilution factor and thus only micromolar to ten-micromolar intracellular concentrations of GSSG can be expected in resting cells. Downs and colleagues have shown that direct application to lung epithelial cells of $400 \mu \mathrm{M}$ GSSG induced decrease in ENaC open probability [63]. This GSSG concentration is at least ten times higher than in resting cell and clearly represents a condition of severe oxidative stress. The inhibitory effect of GSSG was explained by the reversible formation of mixed disulfides between glutathione and low-pKa cysteinyl residues of $\mathrm{ENaC}$ and possibly by irreversible oxidation of the latter [63].

\section{Perspectives and Outlooks}

Epithelial sodium channel $\mathrm{ENaC}$ in the distal nephron is the major ion channel responsible of maintaining $\mathrm{Na}$ homeostasis by fine-tuning of $\mathrm{Na}$ reabsorption, thus playing an important role in the long-term control of arterial pressure. Excess of $\mathrm{ENaC}$ activity leads to systemic hypertension. In the kidney, ENaC is expressed in cortical collecting duct cells (CCD); these cells are able to produce and secrete ROS, particularly hydrogen peroxide [64] which may lead to a stimulation of sodium transport [46]. $\mathrm{H}_{2} \mathrm{O}_{2}$ is very diffusible 
within and between the cells and accordingly $\mathrm{H}_{2} \mathrm{O}_{2}$ generated in kidney could play a role in sodium reabsorption. ROS participate in the regulation of $\mathrm{ENaC}$ and other channels and transporters in the CCD and thus their generation might be linked to diseases associated with ionic channels. It has been shown in several experimental models of hypertension [65] and hypertensive patients [65-67] that ROS levels are increased. In chronic renal insufficiency, $\mathrm{H}_{2} \mathrm{O}_{2}$ levels in situ are increased as well [64]. Moreover, high salt intake can elevate both superoxide $\left[\mathrm{O}_{2}{ }^{--}\right][68-70]$ and $\mathrm{H}_{2} \mathrm{O}_{2}$ in the kidney by stimulating NADPH oxidase [71, 72] and thus furthering sodium retention and aggravating systemic hypertension through modulation of ENaC activity. Moreover, urinary excretion rate of hydrogen peroxide is closely related to metabolism of electrolytes and fluid in the renal tubules [35]. Therefore, it seems that reactive oxygen species play a pathophysiological role in the development of essential hypertension and this may implicate their action on ENaCs $[73,74]$.

Dietary polyphenols from green tea and red vine are well known as blood pressure lowering agents and many studies show an inverse correlation between dietary consumption of these polyphenols and reduced incidence and mortality from cardiovascular diseases [75-77]. A reduction in the markers of oxidative stress induced by dietary polyphenols in different animal models of hypertension could be a mechanism involved in the blood pressure lowering effect $[78,79]$. One cannot exclude direct renal effects in the antihypertensive action of polyphenols, since, for instance, the downregulation of $\mathrm{ENaC}$ in the kidney by flavonoid quercetin contributed to the blood pressure lowering effect in Dahl salt-sensitive hypertension $[80,81]$.

$\mathrm{ENaC}$ is also major player that participates in fluid absorption in the lung. In cystic fibrosis [CF], the absence of functional cystic fibrosis transmembrane regulator channel (CFTR) upregulates the ENaC channel activity and further decreases salt and water secretion by reabsorbing sodium ions. On the other hand, cystic fibrosis lung disease is characterized by chronic airway inflammation and thus oxidative stress, which can be quantified by measurement of hydrogen peroxide in exhaled breath condensate [17, 82]. It is then plausible that increased production of $\mathrm{H}_{2} \mathrm{O}_{2}$ in $\mathrm{CF}$ lungs contributes to sodium hyperabsorption. This suggestion merits an investigation of the link between these two phenomena. In this regard it has been shown that oxidation arising from airway inflammation or environmental exposure contributes to pathologic mucus gel formation in the lung and such antioxidants as polyphenol resveratrol and $\mathrm{N}$-acetylcysteine have clear mucolytic activity $[83,84]$. It would be also interesting to see the effect of nebulized catalase on mucociliary clearance in healthy and CF subjects or in animal models, although it may compromise innate immunity in the lungs.

\section{Conclusion}

Review of the literature suggests that hydrogen peroxide has a stimulatory action on ENaC single-channel activity and on its stability at the membrane while having possible inhibitory action on the transcription of the $\mathrm{ENaC}$ subunits. Under conditions of severe oxidative stress of the cell, this channel activity is inhibited. Modulation of ENaC activity by $\mathrm{H}_{2} \mathrm{O}_{2}$ might contribute to the development of such pathophysiological conditions as systemic hypertension and thickening of the mucus in the CF lungs, although no direct evidence in support of these hypotheses has been provided so far. As a concluding note for perspectives, we suggest that further studies on ENaCs may focus on the action of dietary polyphenols on the activity and expression of this channel in lung and renal epithelial cells. These studies should be performed in conjunction with the measurements of oxidative state of these cells including in situ measurements of absolute values of hydrogen peroxide concentrations.

\section{Competing Interests}

The authors declare that they have no competing interests.

\section{Acknowledgments}

The authors gratefully acknowledge the financial support from the "Fund Alphonse and Jean Forton," "Fund Crawez," and "Fonds d'Encouragement à la Recherche" of ULB.

\section{References}

[1] B. Halliwel and J. M. C. Gutteridge, Free Radicals in Biology and Medicine, Clarendon Press, Oxford, UK, 3rd edition, 1999.

[2] J. A. Imlay and S. Linn, "Mutagenesis and stress responses induced in Escherichia coli by hydrogen peroxide," Journal of Bacteriology, vol. 169, no. 7, pp. 2967-2976, 1987.

[3] M. B. Hampton and S. Orrenius, "Dual regulation of caspase activity by hydrogen peroxide: implications for apoptosis," FEBS Letters, vol. 414, no. 3, pp. 552-556, 1997.

[4] M.-V. Clément, A. Ponton, and S. Pervaiz, "Apoptosis induced by hydrogen peroxide is mediated by decreased superoxide anion concentration and reduction of intracellular milieu," FEBS Letters, vol. 440, no. 1-2, pp. 13-18, 1998.

[5] B. González-Flecha and B. Demple, "Homeostatic regulation of intracellular hydrogen peroxide concentration in aerobically growing Escherichia coli," Journal of Bacteriology, vol. 179, no. 2, pp. 382-388, 1997.

[6] J. B. De Haan, C. Bladier, P. Griffiths et al., "Mice with a homozygous null mutation for the most abundant glutathione peroxidase, Gpxl, show increased susceptibility to the oxidative stress-inducing agents paraquat and hydrogen peroxide," The Journal of Biological Chemistry, vol. 273, no. 35, pp. 2252822536, 1998.

[7] Y.-S. Ho, J.-L. Magnenat, R. T. Bronson et al., "Mice deficient in cellular glutathione peroxidase develop normally and show no increased sensitivity to hyperoxia," Journal of Biological Chemistry, vol. 272, no. 26, pp. 16644-16651, 1997.

[8] S. G. Rhee, "Cell signaling. $\mathrm{H}_{2} \mathrm{O}_{2}$, a necessary evil for cell signaling," Science, vol. 312, pp. 1882-1883, 2006.

[9] S. Matalon, K. M. Hardiman, L. Jain et al., "Regulation of ion channel structure and function by reactive oxygen-nitrogen species," American Journal of Physiology-Lung Cellular and Molecular Physiology, vol. 285, no. 6, pp. L1184-L1189, 2003. 
[10] J. Tkaczyk and M. Vízek, "Oxidative stress in the lung tissuesources of reactive oxygen species and antioxidant defence," Prague Medical Report, vol. 108, no. 2, pp. 105-114, 2007.

[11] K. M. Holmström and T. Finkel, "Cellular mechanisms and physiological consequences of redox-dependent signalling," Nature Reviews Molecular Cell Biology, vol. 15, no. 6, pp. 411-421, 2014.

[12] M. Nakamura, S. Motoyama, S. Saito, Y. Minamiya, R. Saito, and J.-I. Ogawa, "Hydrogen peroxide derived from intestine through the mesenteric lymph induces lung edema after surgical stress," Shock, vol. 21, no. 2, pp. 160-164, 2004.

[13] V. L. Kinnula, L. Chang, J. I. Everitt, and J. D. Crapo, "Oxidants and antioxidants in alveolar epithelial type II cells: in situ, freshly isolated, and cultured cells," American Journal of Physiology_Lung Cellular and Molecular Physiology, vol. 262, no. 1, pp. L69-L77, 1992.

[14] W. J. Piotrowski, J. Marczak, D. Dinsdale et al., "Release of hydrogen peroxide by rat type II pneumocytes in the prolonged culture," Toxicology in Vitro, vol. 14, no. 1, pp. 85-93, 2000.

[15] H. Fischer, L. K. Gonzales, V. Kolla et al., "Developmental regulation of DUOX1 expression and function in human fetal lung epithelial cells," American Journal of Physiology-Lung Cellular and Molecular Physiology, vol. 292, no. 6, pp. L1506L1514, 2007.

[16] R. Forteza, M. Salathe, F. Miot, R. Forteza, and G. E. Conner, "Regulated hydrogen peroxide production by duox in human airway epithelial cells," American Journal of Respiratory Cell and Molecular Biology, vol. 32, no. 5, pp. 462-469, 2005.

[17] P. P. R. Rosias, G. J. M. Den Hartog, C. M. H. H. T. Robroeks et al., "Free radicals in exhaled breath condensate in cystic fibrosis and healthy subjects," Free Radical Research, vol. 40, no. 9, pp. 901-909, 2006.

[18] R. Stolarek, P. Bialasiewicz, M. Krol, and D. Nowak, "Breath analysis of hydrogen peroxide as a diagnostic tool," Clinica Chimica Acta, vol. 411, no. 23-24, pp. 1849-1861, 2010.

[19] S. Loukides, P. Bakakos, and K. Kostikas, "Exhaled breath condensate: hydrogen peroxide," European Respiratory Society Monograph, vol. 49, pp. 162-172, 2010.

[20] S. Radl, S. Ortner, R. Sungkorn, and J. G. Khinast, "The engineering of hydrogen peroxide decontamination systems," Journal of Pharmaceutical Innovation, vol. 4, no. 2, pp. 51-62, 2009.

[21] S. I. Rennard, G. Basset, D. Lecossier et al., "Estimation of volume of epithelial lining fluid recovered by lavage using urea as marker of dilution," Journal of Applied Physiology, vol. 60, no. 2, pp. 532-538, 1985.

[22] W. M. J. Burke, C. M. Roberts, D. H. Bryant et al., "Smokinginduced changes in epithelial lining fluid volume, cell density and protein," European Respiratory Journal, vol. 5, no. 7, pp. 780784, 1992.

[23] B. Capitano, B. A. Potoski, S. Husain et al., "Intrapulmonary penetration of voriconazole in patients receiving an oral prophylactic regimen," Antimicrobial Agents and Chemotherapy, vol. 50, no. 5, pp. 1878-1880, 2006.

[24] K. P. Jones, S. P. Reynolds, S. J. Capper, S. Kalinka, J. H. Edwards, and B. H. Davies, "Measurement of interleukin-6 in bronchoalveolar lavage fluid by radioimmunoassay: differences between patients with interstitial lung disease and control subjects," Clinical \& Experimental Immunology, vol. 83, no. 1, pp. 30-34, 1991.

[25] N. E. Avissar, C. K. Reed, C. Cox, M. W. Frampton, and J. N. Finkelstein, "Ozone, but not nitrogen dioxide, exposure decreases glutathione peroxidases in epithelial lining fluid of human lung," American Journal of Respiratory and Critical Care Medicine, vol. 162, no. 4, pp. 1342-1347, 2000.

[26] C. Ward, F. Thien, J. Secombe, S. Gollant, and E. H. Walters, "Bronchoalveolar lavage fluid urea as a measure of pulmonary permeability in healthy smokers," European Respiratory Journal, vol. 15, no. 2, pp. 285-290, 2000.

[27] E. Lecuona, F. Saldías, A. Comellas, K. Ridge, C. Guerrero, and J. I. Sznajder, "Ventilator-associated lung injury decreases lung ability to clear edema in rats," American Journal of Respiratory and Critical Care Medicine, vol. 159, no. 2, pp. 603-609, 1999.

[28] P.-W. Cheng, T. F. Boat, S. Shaikh, O.-L. Wang, P.-C. Hu, and D. L. Costa, "Differential effects of ozone on lung epithelial lining fluid volume and protein content," Experimental Lung Research, vol. 21, no. 3, pp. 351-365, 1995.

[29] M. Aoki, M. Iguchi, H. Hayashi et al., "Proposal of membrane transport mechanism of protein-unbound ulifloxacin into epithelial lining fluid determined by improved microdialysis," Biological and Pharmaceutical Bulletin, vol. 31, no. 9, pp. 1773$1777,2008$.

[30] C. Ward, R. M. Effros, and E. H. Walters, "Assessment of epithelial lining fluid dilution during bronchoalveolar lavage," European Respiratory Review, vol. 9, no. 66, pp. 32-37, 1999.

[31] A. Goraça and B. Skibska, "Beneficial effect of $\alpha$-lipoic acid on lipopolysaccharide-induced oxidative stress in bronchoalveolar lavage fluid," Journal of Physiology and Pharmacology, vol. 59, no. 2, pp. 379-386, 2008.

[32] V. de Broucker, S. M. Hassoun, S. Hulo et al., "Non-invasive collection of exhaled breath condensate in rats: evaluation of $\mathrm{pH}, \mathrm{H}_{2} \mathrm{O}_{2}$ and $\mathrm{NOx}$ in lipopolysaccharide-induced acute lung injury," Veterinary Journal, vol. 194, no. 2, pp. 222-228, 2012.

[33] M. Corradi, P. Pignatti, G. Brunetti et al., "Comparison between exhaled and bronchoalveolar lavage levels of hydrogen peroxide in patients with diffuse interstitial lung diseases," Acta Biomedica, vol. 79, supplement 1, pp. 73-78, 2008.

[34] S. D. Varma and P. S. Devamanoharan, "Excretion of hydrogen peroxide in human urine," Free Radical Research Communications, vol. 8, no. 2, pp. 73-78, 1990.

[35] N. Kuge, M. Kohzuki, and T. Sato, "Relation between natriuresis and urinary excretion of hydrogen peroxide," Free Radical Research, vol. 30, no. 2, pp. 119-123, 1999.

[36] L. H. Long, P. J. Evans, and B. Halliwell, "Hydrogen peroxide in human urine: implications for antioxidant defense and redox regulation," Biochemical and Biophysical Research Communications, vol. 262, no. 3, pp. 605-609, 1999.

[37] K. Hiramoto, X. Li, M. Makimoto, T. Kato, and K. Kikugawa, "Identification of hydroxyhydroquinone in coffee as a generator of reactive oxygen species that break DNA single strands," Mutation Research, vol. 419, no. 1-3, pp. 43-51, 1998.

[38] P. S. Gill and C. S. Wilcox, "NADPH oxidases in the kidney," Antioxidants and Redox Signaling, vol. 8, no. 9-10, pp. 1597-1607, 2006.

[39] S. D. Varma and P. S. Devamanoharan, "Hydrogen peroxide in human blood," Free Radical Research Communications, vol. 14, no. 2, pp. 125-131, 1991.

[40] F. Lacy, D. T. O’Connor, and G. W. Schmid-Schönbein, "Plasma hydrogen peroxide production in hypertensives and normotensive subjects at genetic risk of hypertension," Journal of Hypertension, vol. 16, no. 3, pp. 291-303, 1998.

[41] E. Deskur, L. Przywarska, P. Dylewicz et al., "Exercise-induced increase in hydrogen peroxide plasma levels is diminished by 
endurance training after myocardial infarction," International Journal of Cardiology, vol. 67, no. 3, pp. 219-224, 1998.

[42] F. Lacy, D. A. Gough, and G. W. Schmid-Schönbein, "Role of xanthine oxidase in hydrogen peroxide production," Free Radical Biology and Medicine, vol. 25, no. 6, pp. 720-727, 1998.

[43] B. Frei, Y. Yamamoto, D. Niclas, and B. N. Ames, "Evaluation of an isoluminol chemiluminescence assay for the detection of hydroperoxides in human blood plasma," Analytical Biochemistry, vol. 175, no. 1, pp. 120-130, 1988.

[44] N. Markadieu, R. Crutzen, D. Blero, C. Erneux, and R. Beauwens, "Hydrogen peroxide and epidermal growth factor activate phosphatidylinositol 3-kinase and increase sodium transport in A6 cell monolayers," American Journal of Physiology-Renal Physiology, vol. 288, no. 6, pp. F1201-F1212, 2005.

[45] N. Markadieu, R. Crutzen, A. Boom, C. Erneux, and R. Beauwens, "Inhibition of insulin-stimulated hydrogen peroxide production prevents stimulation of sodium transport in A6 cell monolayers," American Journal of Physiology-Renal Physiology, vol. 296, no. 6, pp. F1428-F1438, 2009.

[46] H.-P. Ma, "Hydrogen peroxide stimulates the epithelial sodium channel through a phosphatidylinositide 3-kinase-dependent pathway," The Journal of Biological Chemistry, vol. 286, no. 37, pp. 32444-32453, 2011.

[47] D. Trac, B. Liu, A. C. Pao et al., "Fulvene-5 inhibition of Nadph oxidases attenuates activation of epithelial sodium channels in A6 distal nephron cells," American Journal of Physiology-Renal Physiology, vol. 305, no. 7, pp. F995-F1005, 2013.

[48] C. A. Downs, A. Kumar, L. H. Kreiner, N. M. Johnson, and M. N. Helms, " $\mathrm{H}_{2} \mathrm{O}_{2}$ regulates lung epithelial sodium channel $(\mathrm{ENaC})$ via ubiquitin-like protein Nedd8," Journal of Biological Chemistry, vol. 288, no. 12, pp. 8136-8145, 2013.

[49] V. Shlyonsky, A. Goolaerts, R. Van Beneden, and S. SaribanSohraby, "Differentiation of epithelial $\mathrm{Na}^{+}$channel function. An in vitro model," The Journal of Biological Chemistry, vol. 280, no. 25, pp. 24181-24187, 2005.

[50] Y. Takemura, P. Goodson, H. F. Bao, L. Jain, and M. N. Helms, "Racl-mediated NADPH oxidase release of $\mathrm{O}_{2}^{-}$regulates epithelial sodium channel activity in the alveolar epithelium," American Journal of Physiology_Lung Cellular and Molecular Physiology, vol. 298, no. 4, pp. L509-L520, 2010.

[51] M. N. Helms, L. Jain, J. L. Self, and D. C. Eaton, "Redox regulation of epithelial sodium channels examined in alveolar type 1 and 2 cells patch-clamped in lung slice tissue," Journal of Biological Chemistry, vol. 283, no. 33, pp. 22875-22883, 2008.

[52] L. Yu, H.-F. Bao, J. L. Self, D. C. Eaton, and M. N. Helms, "Aldosterone-induced increases in superoxide production counters nitric oxide inhibition of epithelial $\mathrm{Na}$ channel activity in A6 distal nephron cells," American Journal of Physiology-Renal Physiology, vol. 293, no. 5, pp. F1666-F1677, 2007.

[53] H.-C. Wang, M. D. Zentner, H.-T. Deng et al., "Oxidative stress disrupts glucocorticoid hormone-dependent transcription of the amiloride-sensitive epithelial sodium channel $\alpha$-subunit in lung epithelial cells through ERK-dependent and thioredoxinsensitive pathways," Journal of Biological Chemistry, vol. 275, no. 12, pp. 8600-8609, 2000.

[54] H. Xu and S. Chu, "ENaC $\alpha$-subunit variants are expressed in lung epithelial cells and are suppressed by oxidative stress," American Journal of Physiology-Lung Cellular and Molecular Physiology, vol. 293, no. 6, pp. L1454-L1462, 2007.

[55] P. L. Ballard, J. W. Lee, X. Fang et al., "Regulated gene expression in cultured type II cells of adult human lung," American Journal of Physiology_Lung Cellular and Molecular Physiology, vol. 299, no. 1, pp. L36-L50, 2010.

[56] S.-R. Lee, K.-S. Yang, J. Kwon, C. Lee, W. Jeong, and S. G. Rhee, "Reversible inactivation of the tumor suppressor PTEN by $\mathrm{H}_{2} \mathrm{O}_{2}$," Journal of Biological Chemistry, vol. 277, no. 23, pp. 20336-20342, 2002.

[57] N. R. Leslie, D. Bennett, Y. E. Lindsay, H. Stewart, A. Gray, and C. P. Downes, "Redox regulation of PI 3-kinase signaling via inactivation of PTEN," The EMBO Journal, vol. 22, pp. 55015510, 2003.

[58] O. Pochynyuk, Q. Tong, A. Staruschenko, H.-P. Ma, and J. D. Stockand, "Regulation of the epithelial $\mathrm{Na}+$ channel $(\mathrm{ENaC})$ by phosphatidylinositides," American Journal of Physiology-Renal Physiology, vol. 290, no. 5, pp. F949-F957, 2006.

[59] D. V. Ilatovskaya, T. S. Pavlov, V. Levchenko, and A. Staruschenko, "ROS production as a common mechanism of ENaC regulation by EGF, insulin, and IGF-1," American Journal of Physiology-Cell Physiology, vol. 304, no. 1, pp. C102-C111, 2013.

[60] X. Lu, F. Wang, M. Liu et al., "Activation of ENaC in collecting duct cells by prorenin and its receptor PRR: involvement of Nox4-derived hydrogen peroxide," American Journal of Physiology-Renal Physiology, 2015.

[61] K.-J. Kim and D.-J. Suh, "Asymmetric effects of $\mathrm{H}_{2} \mathrm{O}_{2}$ on alveolar epithelial barrier properties," American Journal of Physiology-Lung Cellular and Molecular Physiology, vol. 264, no. 3, pp. L308-L315, 1993.

[62] B. Zhang, J. Liu, X. Ma, P. Zuo, B. C. Ye, and Y. Li, "Ultrasensitive and selective assay of glutathione species in arsenic trioxidetreated leukemia HL-60 cell line by molecularly imprinted polymer decorated electrochemical sensors," Biosensors and Bioelectronics, vol. 80, pp. 491-496, 2016.

[63] C. A. Downs, L. Kreiner, X.-M. Zhao et al., "Oxidized glutathione (GSSG) inhibits epithelial sodium channel activity in primary alveolar epithelial cells," American Journal of Physiology-Lung Cellular and Molecular Physiology, vol. 308, no. 9, pp. L943-L952, 2015.

[64] B. H. Rovin, E. Wurst, and D. E. Kohan, "Production of reactive oxygen species by tubular epithelial cells in culture," Kidney International, vol. 37, no. 6, pp. 1509-1514, 1990.

[65] B. Lassègue, A. San Martín, and K. K. Griendling, "Biochemistry, physiology, and pathophysiology of NADPH oxidases in the cardiovascular system," Circulation Research, vol. 110, no. 10, pp. 1364-1390, 2012.

[66] F. Lacy, M. T. Kailasam, D. T. O’Connor, G. W. SchmidSchönbein, and R. J. Parmer, "Plasma hydrogen peroxide production in human essential hypertension: role of heredity, gender, and ethnicity," Hypertension, vol. 36, no. 5, pp. 878-884, 2000.

[67] J. Redón, M. R. Oliva, C. Tormos et al., "Antioxidant activities and oxidative stress byproducts in human hypertension," Hypertension, vol. 41, no. 5, pp. 1096-1101, 2003.

[68] T. Mori, P. M. O'Connor, M. Abe, and A. W. Cowley Jr., "Enhanced superoxide production in renal outer medulla of dahl salt-sensitive rats reduces nitric oxide tubular-vascular cross-talk," Hypertension, vol. 49, no. 6, pp. 1336-1341, 2007.

[69] M. Abe, P. O’Connor, M. Kaldunski, M. Liang, R. J. Roman, and A. W. Cowley Jr., "Effect of sodium delivery on superoxide and nitric oxide in the medullary thick ascending limb," American Journal of Physiology-Renal Physiology, vol. 291, no. 2, pp. F350-F357, 2006.

[70] N. E. Taylor and A. W. Cowley Jr., "Effect of renal medullary $\mathrm{H} 2 \mathrm{O} 2$ on salt-induced hypertension and renal injury," American 
Journal of Physiology-Regulatory Integrative and Comparative Physiology, vol. 289, no. 6, pp. R1573-R1579, 2005.

[71] N. E. Taylor, P. Glocka, M. Liang, and A. W. Cowley Jr., "NADPH oxidase in the renal medulla causes oxidative stress and contributes to salt-sensitive hypertension in Dahl S rats," Hypertension, vol. 47, no. 4, pp. 692-698, 2006.

[72] C. Kitiyakara, T. Chabrashvili, Y. Chen et al., "Salt intake, oxidative stress, and renal expression of NADPH oxidase and superoxide dismutase," Journal of the American Society of Nephrology, vol. 14, no. 11, pp. 2775-2782, 2003.

[73] H. Takahashi, M. Yoshika, Y. Komiyama, and M. Nishimura, "The central mechanism underlying hypertension: a review of the roles of sodium ions, epithelial sodium channels, the reninangiotensin-aldosterone system, oxidative stress and endogenous digitalis in the brain," Hypertension Research, vol. 34, no. 11, pp. 1147-1160, 2011.

[74] A. W. Jr. Cowley, M. Abe, T. Mori, P. M. O’Connor, Y. Ohsaki, and N. N. Zheleznova, "Reactive oxygen species as important determinants of medullary flow, sodium excretion, and hypertension," American Journal of Physiology-Renal Physiology, vol. 308, no. 3, pp. F179-F197, 2015.

[75] T. Watanabe, Y. Arai, Y. Mitsui et al., "The blood pressurelowering effect and safety of chlorogenic acid from green coffee bean extract in essential hypertension," Clinical and Experimental Hypertension, vol. 28, no. 5, pp. 439-449, 2006.

[76] E. Ros, "Nuts and CVD," British Journal of Nutrition, vol. 113, supplement 2, pp. S111-S120, 2015.

[77] O. D. Rangel-Huerta, B. Pastor-Villaescusa, C. M. Aguilera, and A. Gil, "A systematic review of the efficacy of bioactive compounds in cardiovascular disease: phenolic compounds," Nutrients, vol. 7, no. 7, pp. 5177-5216, 2015.

[78] E. L. Schiffrin, "Antioxidants in hypertension and cardiovascular disease," Molecular Interventions, vol. 10, no. 6, pp. 354-362, 2010.

[79] H. N. Siti, Y. Kamisah, and J. Kamsiah, "The role of oxidative stress, antioxidants and vascular inflammation in cardiovascular disease (a review)," Vascular Pharmacology, vol. 71, pp. 4056, 2015.

[80] W. Aoi, N. Niisato, H. Miyazaki, and Y. Marunaka, "Flavonoidinduced reduction of ENaC expression in the kidney of Dahl salt-sensitive hypertensive rat," Biochemical and Biophysical Research Communications, vol. 315, no. 4, pp. 892-896, 2004.

[81] I. Mackraj, T. Govender, and S. Ramesar, "The antihypertensive effects of quercetin in a salt-sensitive model of hypertension," Journal of Cardiovascular Pharmacology, vol. 51, no. 3, pp. 239$245,2008$.

[82] C. M. H. H. T. Robroeks, M. H. Roozeboom, P. A. de Jong et al., "Structural lung changes, lung function, and non-invasive inflammatory markers in cystic fibrosis," Pediatric Allergy and Immunology, vol. 21, no. 3, pp. 493-500, 2010.

[83] S. Yuan, M. Hollinger, M. E. Lachowicz-Scroggins et al., "Oxidation increases mucin polymer cross-links to stiffen airway mucus gels," Science Translational Medicine, vol. 7, no. 276, Article ID 276ra27, 2015.

[84] S. Zhang, A. C. Blount, C. M. McNicholas et al., "Resveratrol enhances airway surface liquid depth in sinonasal epithelium by increasing cystic fibrosis transmembrane conductance regulator open probability," PLoS ONE, vol. 8, no. 11, Article ID e81589, 2013. 

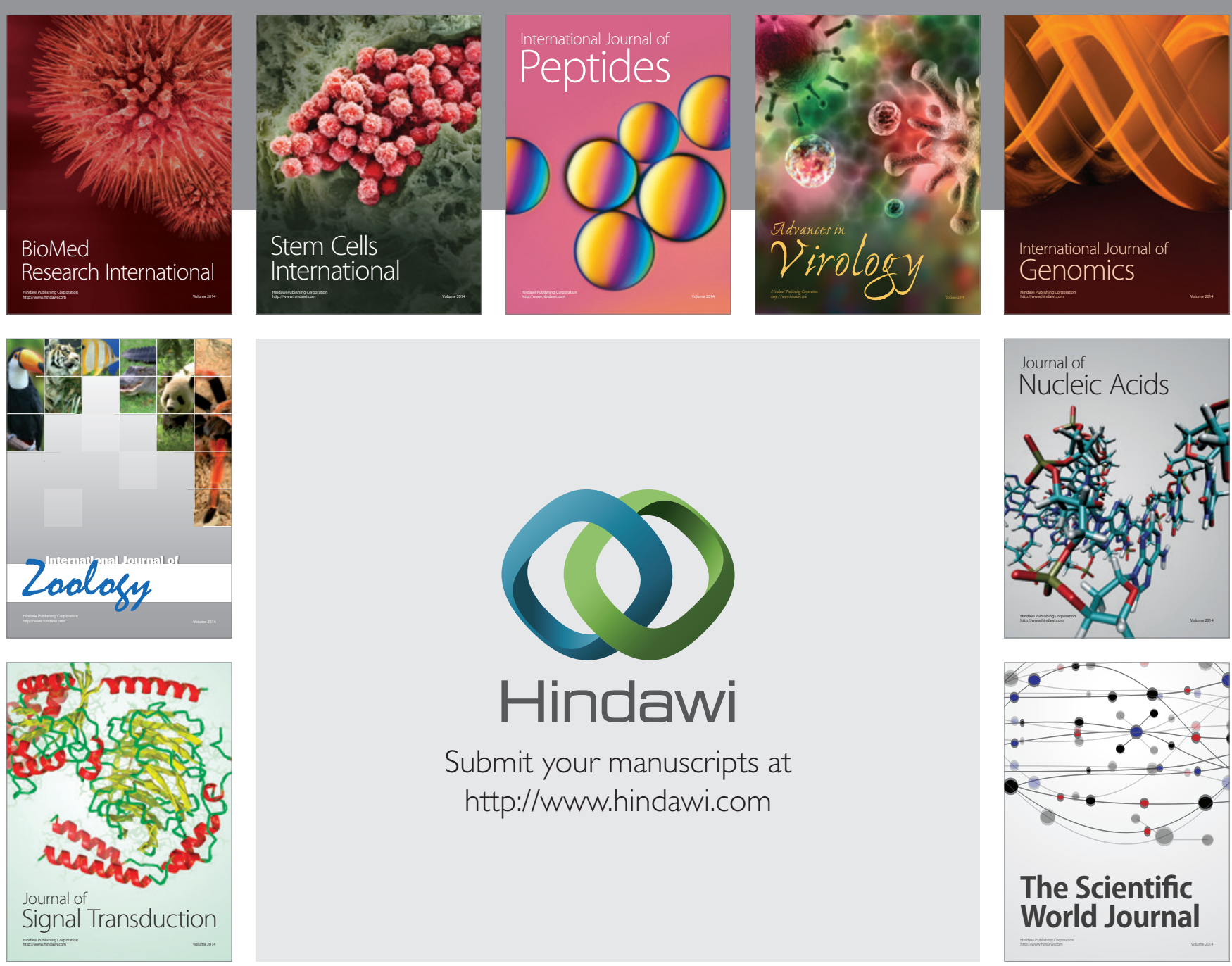

Submit your manuscripts at

http://www.hindawi.com
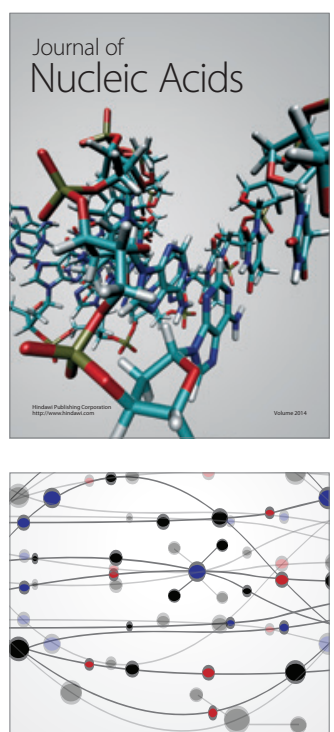

The Scientific World Journal
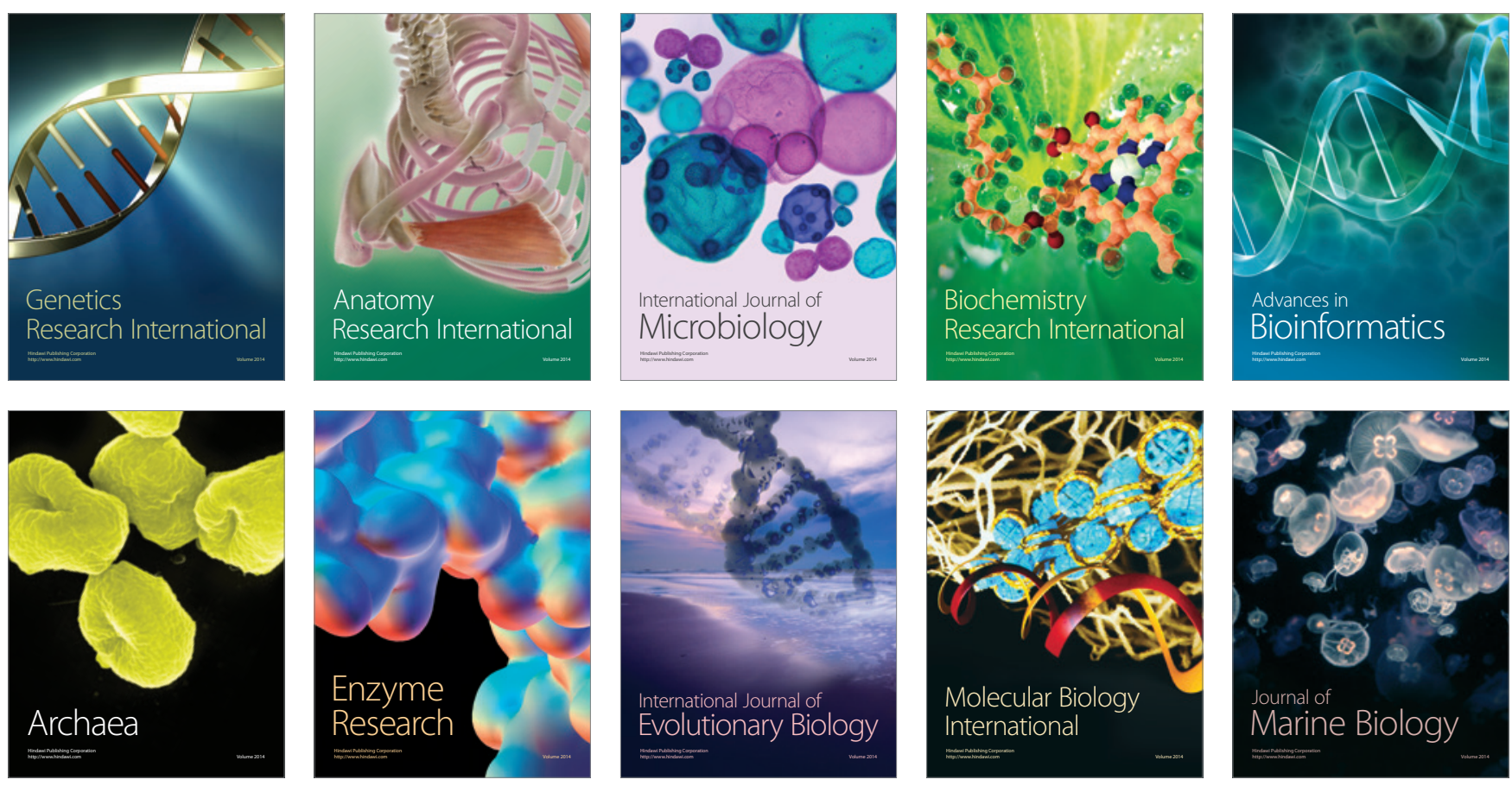